\title{
Purification and characterization of $\beta$-glucosidase from Melanocarpus sp. MTCC 3922
}

\author{
Jatinder Kaur \\ Department of Microbiology \\ Guru Nanak Dev University \\ Amritsar 143005, India \\ Tel: 911832258506 \\ E-mail: jatinderkaur77@yahoo.com

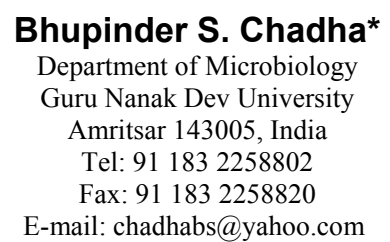

Badhan A. Kumar

Department of Microbiology Guru Nanak Dev University

Amritsar 143005, India Tel: 911832258802 09. Ext. 3317

E-mail: badhanak@yahoo.co.in

$$
\begin{gathered}
\text { Ghatora, S. Kaur } \\
\text { Department of Microbiology } \\
\text { Guru Nanak Dev University } \\
\text { Amritsar 143005, India } \\
\text { Tel: } 911852 \text { 228868 } \\
\text { E-mail: ghatorask@yahoo.com }
\end{gathered}
$$

\section{Harvinder S. Saini}

Department of Microbiology Guru Nanak Dev University

Amritsar 143005, India

Tel: 911832258802 09. Ext. 3318

E-mail: sainihs@yahoo.com

Financial support: The financial support in form of project fellowship provided by Guru Nanak Dev University, Amritsar (India).

Keywords: $\beta$-glucosidase, Melanocarpus sp., purification, substrate specificity, transglycosylation.

Abbreviations:

\author{
IEF: Isoelectric focusing \\ MTCC: Microbial Type Culture Collection \\ PBE: Poly-buffer exchanger \\ pNPG: p-nitrophenyl- $\beta$-D-glicopyronoside \\ SSF: Solid-state fermentation \\ YpSS: Yeast potato soluble starch agar
}

This study reports the purification and characterization of $\beta$-glucosidase from a newly isolated thermophilic fungus, Melanocarpus sp. Microbial Type Culture Collection (MTCC) 3922. The molecular weight of $\beta$ glucosidase was determined to be $\sim 92$ and $102 \mathrm{kDa}$ with SDS PAGE and gel filtration, respectively, and $\mathrm{p} I$ of $~$ 4.1. It was optimally active at $60^{\circ} \mathrm{C}$ and $\mathrm{pH} 6.0$, though was stable at $50^{\circ} \mathrm{C}$ and $\mathrm{pH} 5.0-6.0$. The presence of
DTT, mercaptoethanol and metal ions such as $\mathrm{Na}^{+}, \mathrm{K}^{+}$, $\mathrm{Ca}^{2+}, \mathrm{Mg}^{2+}$ and $\mathrm{Zn}^{2+}$ positively influenced the activity of $\beta$-glucosidase but the activity was inhibited in the presence of $\mathrm{CuSO}_{4}$. $\beta$-Glucosidase recognized pNP- $\beta$ glucopyranoside (pNPG) as the preferred substrate, and showed very low affinity for pNP- $\beta$-D-cellobioside. $K_{m}$ and $V_{\max }$ for the hydrolysis of pNPG by $\beta$-glucosidase was calculated as $3.3 \mathrm{mM}$ and $43.68 \mu \mathrm{molmin}^{-1} \mathrm{mg}$

*Corresponding author 
$\operatorname{protein}^{-1}$, respectively and $k_{\text {cat }}$ was quantified as $4 \times 10^{3}$ $\min ^{-1}$. $\beta$-Glucosidase activity was enhanced appreciably in the presence of alcohols (methanol and ethanol) moreover, purified $\beta$-glucosidase showed putative transglycosylation activity that was positively catalyzed in presence of methanol as an acceptor molecule.

Cellulose, which constitutes the highest proportion of municipal and plant wastes, represents a major source of renewable energy and raw materials. Therefore, the utilization of cellulosic wastes to produce energy is potentially of great importance. Cellulases bring about the hydrolysis of cellulose, a homo-polymer of $\beta-1,4$ linked glucose units that comprises of amorphous and crystalline regions, by synergistic action of its constituent enzymes. These enzymes include; a) $\beta$-1,4-endoglucanase $(1,4-\beta$-Dglucan 4-glucanohydrolase; EC 3.2.1.4, cellulase), which cleaves internal $\beta$-1,4-glycosidic bonds, b) cellobiohydrolase (1,4- $\beta$-D-glucan cellobiohydrolase; EC 3.2.1.91, cellulase 1,4- $\beta$-cellobiosidase), an exo-acting enzyme which releases cellobiose from reducing and non reducing ends of cellulose and c) $\beta$-glucosidase ( $\beta$-Dglucoside glucohydrolase; EC 3.2.1.21, cellulase 1,4- $\beta$ glucosidase) that hydrolyzes cellobiose to glucose (Bhat and Bhat, 1997). $\beta$-glucosidase is generally responsible for the regulation of the whole cellulolytic process and is a rate-limiting factor during enzymatic hydrolysis of cellulose, as both endoglucanase and exoglucanase

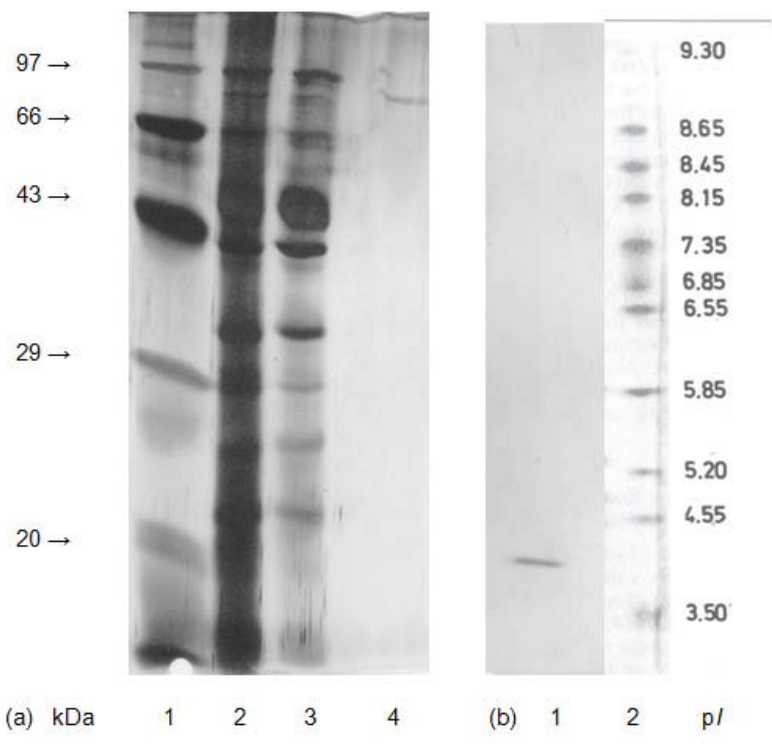

Figure 1. Analysis of purified $\beta$-glucosidase from Melanocarpus sp. $\quad$ MTCC 3922.

(a) SDS-PAGE of purified Lane 1, standard protein markers in the order of increasing molecular mass: Soyabean trypsin inhibitor (20 kDa); Carbonic anhydrase (29 kDa); Ovalbumin (43 kDa); Bovine serum albumin (66 kDa); Phosphorylase b (97.4 kDa); Lane 2, crude protein; Lane 3, protein from pool 1 of DEAE-Sepharose column; Lane 4 , protein of purified $\beta$ glucosidase after PBE-94 column. (b) Iso-electric focusing of purified $\beta$-glucosidase, Lane 1, protein of purified $\beta$-glucosidase after PBE-94 column and Lane 2 standard $p /$ markers. activities are often inhibited by cellobiose (Harhangi et al. 2002). Thus, $\beta$-glucosidase not only produces glucose from cellobiose, but also reduces cellobiose inhibition, allowing endoglucanase and exoglucanase enzymes to function more efficiently.

$\beta$-Glucosidase from Aspergillus supplemented to Trichoderma reesei cellulase preparations, plays an important role for cellulose saccharification on an industrial scale (Reczey et al. 1998). In recent years, interest in $\beta$ glucosidase has gained momentum owing to their ability to catalyze transglycosylation reactions. These types of reactions have great importance in wine industry because of its ability to improve the aroma of wines. The glycosylated precursor such as terpenes (Caldini et al. 1994) is found in mango, passion fruits and grapes (Sarry and Gunata, 2004) and $\beta$-glucosidases are more effective and specific than acid hydrolysis process for liberating terpenol (i.e., volatile alcohols) from terpenylglucoside. These glycosidically bound volatiles also have interest in the food, cosmetic and tobacco industries (Jerković and Mastelić, 2004). Saccharomyces cerevisiae cannot utilize cellulosic materials; therefore for the direct conversion of cellulose to ethanol various cellulase and $\beta$-glucosidase genes have been expressed in S. cerevisiae (Van Rensburg et al. 1998). A recent U.S. patent 5,454,389 reports that a crude cellulase having high ratio of $\beta$-glucosidase activity to filter paper units provide improved efficiency of deinking (Yang et al. 1999).

Although, there are number of reports on the production of $\beta$-glucosidase from yeast (S. cerevisiae, Pichia etchellsii) and mesophilic fungi (Trichoderma harzianum and Aspergillus sp.). Recent reports suggest that thermophilic fungi (Thermoascus aurantiacus, Chaetomium thermophile, Humicola insolens, Sporotrichum thermophile) and hydrocarbon utilizing novel fungus Cladosporium resinae are also good sources of $\beta$-glucosidase (Pandey and Mishra, 1997; Iwashita et al. 1998; Van Rensburg et al. 1998; Oh et al. 1999; Maheshwari et al. 2000; Parry et al. 2001; Yun et al. 2001). Recently, we have reported endoglucanase and $\beta$ glucosidase production from a rare thermophilic fungus Melanocarpus sp. Microbial Type Culture Collection (MTCC) 3922 (Kaur et al. 2006), a fungus initially reported to be devoid of cellulases (Maheshwari and Kamalam, 1985). This study for the first time reports the purification and characterization of $\beta$-glucosidase from Melanocarpus sp. MTCC 3922.

\section{MATERIALS AND METHODS}

\section{Culture}

A thermophilic fungus isolated from composting soil and identified as Melanocarpus sp. MTCC 3922 was employed in this study. The fungus was grown and maintained on yeast potato soluble starch agar (YpSS) of following composition $(\% \mathrm{w} / \mathrm{v})$ : starch, 1.5 ; yeast extract, 0.4 ; $\mathrm{KH}_{2} \mathrm{PO}_{4}, 0.2 ; \mathrm{K}_{2} \mathrm{HPO}_{4}, 0.23 ; \mathrm{MgSO}_{4} .7 \mathrm{H}_{2} \mathrm{O}, 0.05$; citric 
a

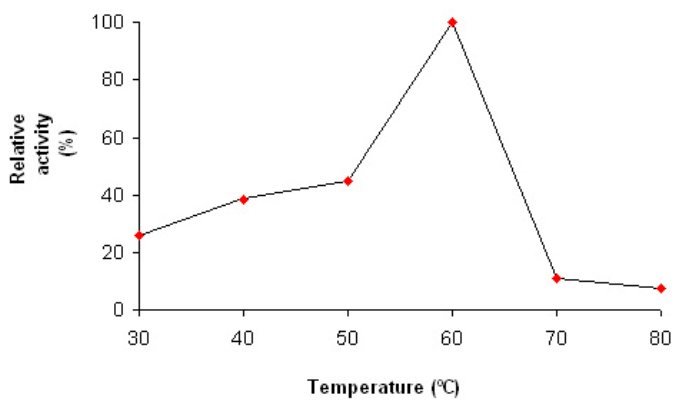

b

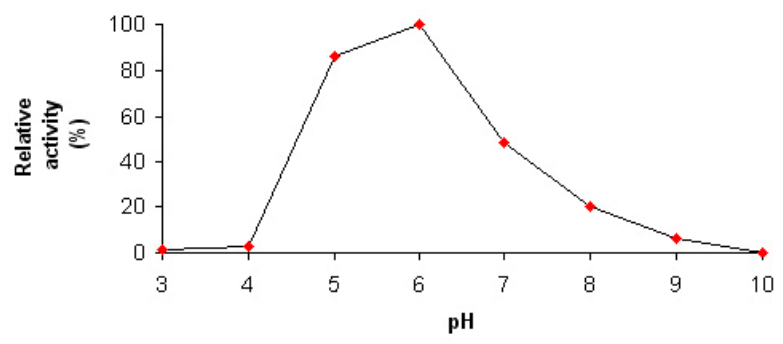

Figure 2. Optimal temperature (a) and $\mathrm{pH}$ (b) of $\beta$ glucosidase from Melanocarpus sp. MTCC 3922.

acid, 0.057 and agar, 2.0. The $\mathrm{pH}$ of medium was adjusted to 7.0 . The fungus was cultured at $45^{\circ} \mathrm{C}$ for 7 days and stored at $4^{\circ} \mathrm{C}$.

\section{Production of $\beta$-glucosidase}

For the preparation of inoculum, the culture was grown in $500 \mathrm{ml}$ Erlenmeyer flask containing $100 \mathrm{ml}$ glucose-urea medium of the following composition $(\% \mathrm{w} / \mathrm{v})$; glucose, 1.0 ; yeast extract, $1.0 ; \quad \mathrm{KH}_{2} \mathrm{PO}_{4}, 0.6 ; \mathrm{K}_{2} \mathrm{HPO}_{4}, 0.04$; $\mathrm{MgSO}_{4} .7 \mathrm{H}_{2} \mathrm{O}$, 0.05; urea, 0.05. During shake flask culturing few glass beads ( $1 \mathrm{~cm}$ in diameter) were added to the flasks to avoid clumping of the mycelium so as to attain homogeneous growth. The $\mathrm{pH}$ of the medium was adjusted to 6.0 and flasks were incubated in an orbital shaker (120 rpm) at $45^{\circ} \mathrm{C}$ for $72 \mathrm{hrs}$.

Solid-state fermentation (SSF) was carried out in $500 \mathrm{ml}$ Erlenmeyer flasks that contained $10.0 \mathrm{~g}$ of rice straw as carbon source and $35 \mathrm{ml}$ of basal salt medium of following compositions $(\% \quad \mathrm{w} / \mathrm{v})$ : urea, $1.5 ; \quad \mathrm{KH}_{2} \mathrm{PO}_{4}, \quad 0.12$; $\mathrm{MgSO}_{4} .7 \mathrm{H}_{2} \mathrm{O}, 0.05 ; \mathrm{CaCl}_{2} 2 \mathrm{H}_{2} \mathrm{O}, 0.01$ and $(1 \% \mathrm{v} / \mathrm{v})$ trace element solution $(\% \mathrm{w} / \mathrm{v})$ : $\left(\mathrm{NH}_{4}\right)_{2} \mathrm{SO}_{4}, 0.2 ; \mathrm{KCl}, 0.5 ; \mathrm{CaCl}_{2}$, $0.1 ; \mathrm{MgSO}_{4}, 0.5 ; \mathrm{ZnSO}_{4}, 0.01$ and $\mathrm{CuSO}_{4}, 0.005$. The basal medium was supplemented with Tween $20(0.1 \% \mathrm{v} / \mathrm{v})$. The initial moisture content of the medium was adjusted to $80 \%$. Prior to sterilization, the initial $\mathrm{pH}$ of the medium was adjusted to 6.0. The sterile production medium was inoculated with $4 \mathrm{ml}$ of the culture grown on glucose-urea medium and incubated in a water-saturated atmosphere at $45^{\circ} \mathrm{C}$ for 7 days. After incubation, $100 \mathrm{ml}$ sodium citrate buffer $(50 \mathrm{mM}, \mathrm{pH} 6.0)$ was added to flasks, and these flasks were kept at $50^{\circ} \mathrm{C}$ for $1 \mathrm{hr}$ under mild stirring. The fermented slurry was filtered through muslin cloth and centrifuged at $11000 \mathrm{Xg}$ for $15 \mathrm{~min}$. The filtrate was concentrated using Amicon cell fitted with a PM-10 membrane (10 kDa cut off) and used for $\beta$-glucosidase purification.

\section{Purification of $\beta$-glucosidase}

lon-exchange chromatography (DEAE Sepharose). The concentrated sample was centrifuged $(10,000 \mathrm{x} \mathrm{g}$ for 20 $\mathrm{min}$ ) and loaded on DEAE-Sepharose (FF) column (24 x $2.6 \mathrm{~cm}$, Pharmacia), equilibrated with sodium acetate buffer (20 mM, pH 5.0). The column was eluted first with equilibration buffer ( 2 bed volumes) followed by linear gradient of $0-1.0 \mathrm{M} \mathrm{NaCl}$ in acetate buffer $(20 \mathrm{mM}, \mathrm{pH} 5.0)$ at a flow rate of $1 \mathrm{ml} \mathrm{min}{ }^{-1}$. The fractions were assayed for $\beta$-glucosidase and active fractions were pooled, desalted and concentrated using Amicon ultra-filtration cell fitted with a PM-10 membrane (Millipore).

Poly-buffer exchanger (PBE 94). $\beta$-Glucosidase was further purified using column $(10 \times 0.75 \mathrm{~cm})$ packed with poly-buffer exchanger (PBE-94; Pharmacia Biotech). The column was pre-equilibrated with sodium acetate buffer (20 $\mathrm{mM}, \mathrm{pH}$ 5.0). The sample applied was eluted with sodium

Table 1. Summary of purification of $\beta$-glucosidase from Melanocarpus sp. MTCC 3922.

\begin{tabular}{|c|c|c|c|c|c|}
\hline $\begin{array}{l}\text { Purification } \\
\text { step }\end{array}$ & $\begin{array}{l}\text { Total activity } \\
\text { (units) }\end{array}$ & $\begin{array}{l}\text { Total protein } \\
\text { (mg) }\end{array}$ & $\begin{array}{c}\text { Specific activity } \\
\left(\mu \mathrm{mol} \min ^{-1}\right. \\
\left.\text { mg protein }^{-1}\right)\end{array}$ & $\begin{array}{c}\text { Fold } \\
\text { purification }\end{array}$ & $\begin{array}{c}\text { Yield } \\
\text { (\% recovery) }\end{array}$ \\
\hline Culture filtrate & 4895.0 & 1975.0 & 2.47 & - & 100 \\
\hline Ultra- filtration & 4104.0 & 1445.2 & 2.8 & 1.13 & 83.84 \\
\hline DEAE-Sepharose & 1476.0 & 197.3 & 7.48 & 3.03 & 30.15 \\
\hline PBE-94 & 778.0 & 77.47 & 10.04 & 4.06 & 15.89 \\
\hline
\end{tabular}



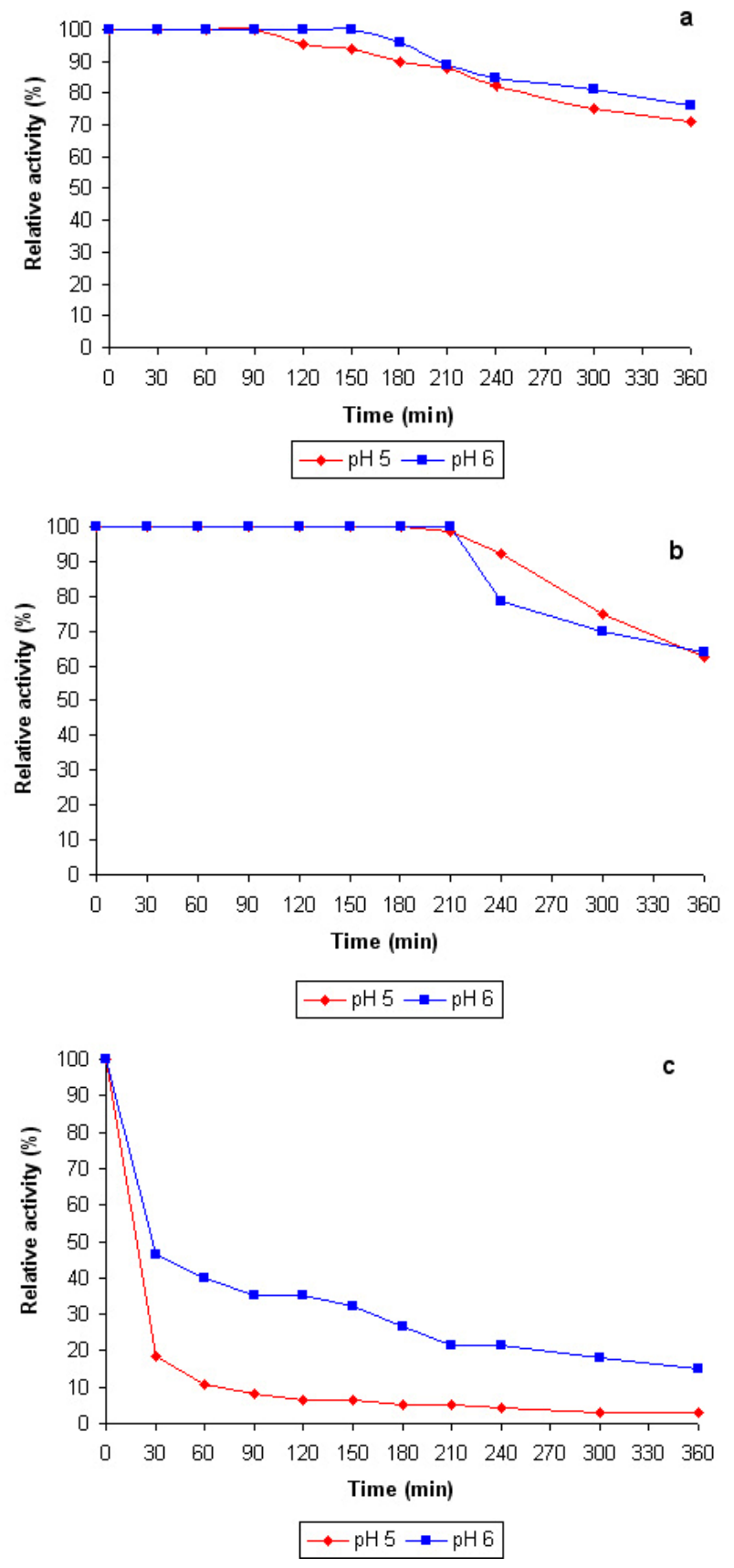

Figure 3. Stability of $\beta$-glucosidase from Melanocarpus sp. MTCC 3922 at $\mathrm{pH} 5.0$ and 6.0at different temperatures: (a) Temperature $40^{\circ} \mathrm{C}$ as a function of time.

(b) Temperature $50^{\circ} \mathrm{C}$ as a function of time.

(c) Temperature $60^{\circ} \mathrm{C}$ as a function of time.

acetate buffer $(20 \mathrm{mM}, \mathrm{pH} 5.0)$ by 3 bed volumes and followed by linear gradient of $0-1.0 \mathrm{M} \mathrm{NaCl}$ in acetate buffer (20 mM, pH 5.0) at a flow rate of $0.2 \mathrm{ml} \mathrm{min}^{-1}$. The fractions were collected using automated liquid chromatography system (ÄKTA Pharmacia Biotech). Purified fractions containing $\beta$-glucosidase were pooled for biochemical assays.

\section{Assay of $\beta$-glucosidase}

$\beta$-Glucosidase was assayed using p-nitrophenyl- $\beta$-Dglucopyranoside (pNPG) by micro titer plate method as described (Parry et al. 2001). A reaction mixture $(100 \mu \mathrm{l})$ containing $25 \mu \mathrm{l}$ of enzyme, $25 \mu \mathrm{l}$ of pNPG $(10 \mathrm{mM})$ as substrate and sodium acetate buffer $(50 \mathrm{mM}, \mathrm{pH} 5.0)$ was incubated at $50^{\circ} \mathrm{C}$ for $30 \mathrm{~min}$, the reaction was terminated by addition of $100 \mu \mathrm{l}$ of $\mathrm{NaOH}$-glycine buffer $(0.4 \mathrm{M}, \mathrm{pH}$ 10.8). The developed yellow colour was read at $405 \mathrm{~nm}$ using ELISA Reader (MULTISKAN; Labsystems). The amount of p-nitrophenol released was quantified using the pNP standard. One unit of $\beta$-glucosidase activity was expressed as the amount of enzyme required to release 1 $\mu$ mole of pNP per minute under the assay conditions. However, during purification $50 \mu \mathrm{l}$ of enzyme was used for assay.

\section{Determination of protein}

The protein was determined by protein dye binding method of Bradford (1976). Absorbance at $280 \mathrm{~nm}$ was used to monitor the protein content in the column fractions.

\section{Characterization of $\beta$-glucosidase}

Gel Filtration, SDS-PAGE and IEF. The homogeneity and molecular mass of $\beta$-glucosidase was determined by gel filtration and SDS-PAGE. The gel filtration of purified $\beta$ glucosidase $(10 \mu \mathrm{g})$ and standard protein markers (Bangalore GENEI, India) comprising of $\beta$-galactosidase $(116 \mathrm{kDa})$, bovine serum albumin $(66 \mathrm{kDa})$ and carbonic anhydrase $(29 \mathrm{kDa})$ was carried out on a Sephacryl HR 200 column $(1.8 \times 90 \mathrm{~cm})$. The column was equilibrated with sodium acetate buffer $(50 \mathrm{mM}, \mathrm{pH} 5.0)$, containing $10 \mathrm{mM}$ $\mathrm{NaCl}$ and eluted at a flow rate of $12 \mathrm{mlh}^{-1}$. The fractions $(2.5 \mathrm{ml})$ were assayed for $\beta$-glucosidase and protein. SDSPAGE was performed using acrylamide gel $(10 \%)$ by the method of Laemmli (Laemmli, 1970) using Bio-Rad miniprotean II electrophoresis unit. The protein markers were run along side of the sample (10 $\mu \mathrm{g}$ protein sample was used) and protein bands were visualized by silver staining method. The $\mathrm{M}_{\mathrm{r}}$ of $\beta$-glucosidase was determined using the plot of $\log \mathrm{M}_{\mathrm{r}}$ of the standard protein markers versus their elution volume (gel filtration) and relative mobility (SDSPAGE).

Isoelectric focusing (IEF) was performed according to the instructions provided by Novex, using 5\% acrylamide gel containing $2.4 \%$ broad $\mathrm{pH}$ range (3.5-10.0) ampholine carrier ampholyte. The cathode buffer contained lysine $2.9 \%(\mathrm{w} / \mathrm{v})$ and $\operatorname{arginine} 3.5 \%(\mathrm{w} / \mathrm{v})$, whereas, phosphoric acid $(10 \mathrm{mM})$ was used as anode buffer. Isoelectric focusing was carried out for $1 \mathrm{hr}$ each at constant voltage of $100 \mathrm{~V}$ and $200 \mathrm{~V}$ followed with $500 \mathrm{~V}$ for $30 \mathrm{~min}$. The gel was fixed in TCA $(10 \% \mathrm{w} / \mathrm{v})$ for $2 \mathrm{hrs}$ and silver staining was performed. The $\mathrm{p} I$ of $\beta$-glucosidase was determined using the plot of relative mobility of standard protein $\mathrm{p} I$ markers (FLUKA) versus their $\mathrm{p} I$. 


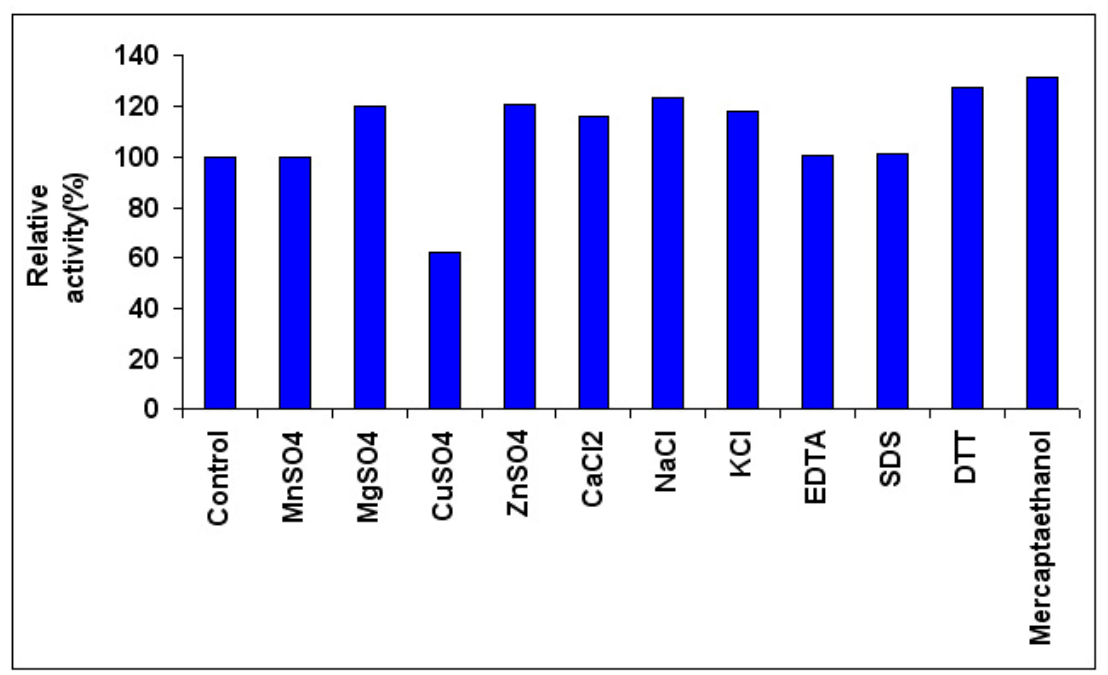

Figure 4. Effect of metal ions and other chemical reagents (10 $\mathrm{mM}$ each) on $\beta$-glucosidase activity from Melanocarpus sp. MTCC 3922. The experiment was carried out in triplicates and experimental error was in the range of $1-5 \%$.

Temperature and $\mathbf{p H}$ optima and stability. The temperature profile of purified $\beta$-glucosidase was obtained by determining the activity on pNPG between 30 and $80^{\circ} \mathrm{C}$. The optimal $\mathrm{pH}$ was determined by measuring the activity between $\mathrm{pH} 3.0$ and $10.0(50 \mathrm{mM})$ using acetate buffer $(\mathrm{pH}$ 3.0-5.0), phosphate buffer ( $\mathrm{pH} 6.0-8.0)$, and glycine-NaOH $(\mathrm{pH} 9.0-10.0)$ at $50^{\circ} \mathrm{C}$. For the determination of temperature and $\mathrm{pH}$ stability, the enzyme was pre-incubated in the temperature range of $50^{\circ} \mathrm{C}$ and $60^{\circ} \mathrm{C}$ for $0-6 \mathrm{hrs}$, or in the initial $\mathrm{pH}$ range $5.0-6.0$ at $50^{\circ} \mathrm{C}$ and $60^{\circ} \mathrm{C}$, respectively, and assayed for $\beta$-glucosidase activity using $\mathrm{pNPG}$ as substrate.

Effect of metal ions and other reagents. $\beta$-Glucosidase was incubated in $10 \mathrm{mM}$ (final concentration) of $\mathrm{MnSO}_{4}$, $\mathrm{CaCl}_{2}, \mathrm{MgSO}_{4}, \mathrm{EDTA}, \mathrm{NaCl}, \mathrm{KCl}, \mathrm{CuSO}_{4}, \mathrm{SDS}, \mathrm{ZnSO}_{4}$, DTT, and mercaptoethanol for $30 \mathrm{~min}$ at room temperature and the activities were determined thereafter using pNPG as substrate.

Substrate specificity. Substrate specificity of $\beta$ glucosidase was determined by using pNP- $\beta$ glucopyranoside, $\quad$ NP- $\alpha$-D-glucopyranoside, $\quad \mathrm{pNP}-\beta$ galactopyranoside, oNP- $\beta$-D-galactopyranoside, oNP- $\beta$-Dxylopyranoside, pNP- $\beta$-D-xylopyranoside and pNPcellobioside, $(3 \mathrm{mM})$ as substrates. A reaction mixture (150 $\mu \mathrm{l})$ containing $50 \mu \mathrm{l}$ substrate, $50 \mu \mathrm{l}$ of purified enzyme and acetate buffer $(50 \mathrm{mM}, \mathrm{pH} 5.0)$ was incubated at $50^{\circ} \mathrm{C}$ for 1 $\mathrm{hr}$. The reaction was terminated by addition of $150 \mu \mathrm{l}$ glycine- $\mathrm{NaOH}$ buffer $(0.4 \mathrm{M}, \mathrm{pH} 10.8)$. The colour developed was read at $405 \mathrm{~nm}$ using ELISA Reader (MULTISKAN; Labsystems). The activities on polysaccharides (CMC (low viscosity), CMC (high viscosity), solka floc, birch wood xylan, laminarin and avicel) were determined by incubating reaction mixture (1 ml) containing $100 \mu \mathrm{l}$ enzyme, $400 \mu \mathrm{l}$ citrate buffer (50
$\mathrm{mM}, \mathrm{pH} 5.0)$ and $500 \mu \mathrm{l}$ of respective substrate $(1 \% \mathrm{w} / \mathrm{v})$ at $50^{\circ} \mathrm{C}$ for $1 \mathrm{hr}$. The reducing sugars released were quantified using DNS reagent. The activities on cellobiose and salicin ( $3 \mathrm{mM}$ ) were estimated by assaying the amount of released glucose using GOD-POD method (Lin et al. 1999). The apparent $K_{\mathrm{m}}, V_{\max }$, and $\mathrm{k}_{\text {cat }}$ for $\beta$-glucosidase were determined against pNPG using Lineweaver Burk plot.

Effect of mono/disaccharides on $\boldsymbol{\beta}$-glucosidase. The effect of mono/disaccharides $(1 \mathrm{mg} / \mathrm{ml})$ on $\beta$-glucosidase activity was studied using pNPG as a substrate.

Effect of alcohols. The effect of methanol, ethanol and propan-2-ol $(0-100 \% \mathrm{v} / \mathrm{v})$ on the hydrolysis of $\mathrm{pNPG}$ were studied using the pNPG assay.

Table 2. Relative activities towards aryl substrates, cellobiose and salicin on $\beta$-glucosidase from Melanocarpus sp. MTCC 3922.

\begin{tabular}{|c|c|}
\hline Substrate (3 mM) & Relative activity (\%) \\
\hline pNP- $\beta$-glucopyranoside & 100 \\
\hline pNP-cellobioside & 4.69 \\
\hline Cellobiose & 24.33 \\
\hline Salicin & 4.37 \\
\hline
\end{tabular}

Activities were determined by measuring glucose as described in materials and methods. 


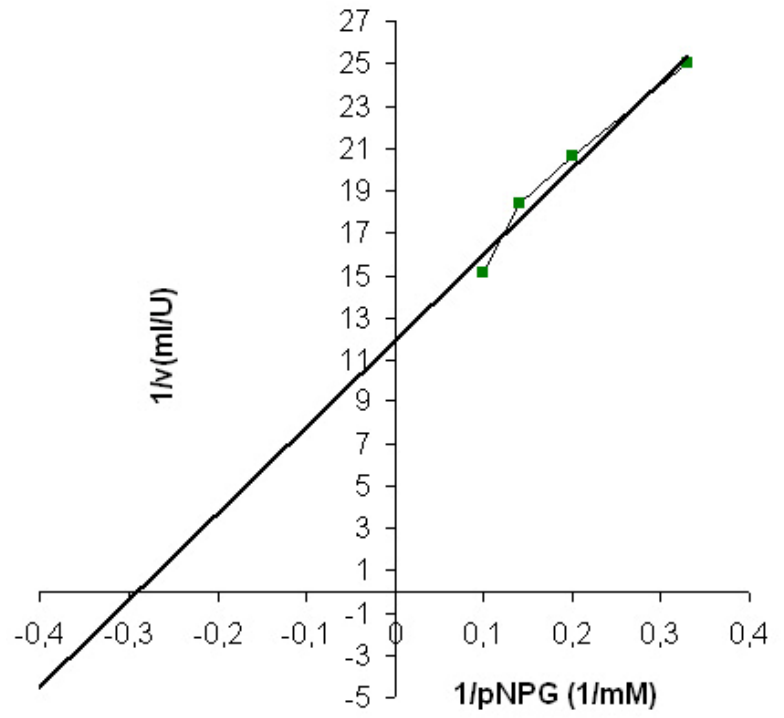

Figure 5. Effect of various concentrations of pNPG on $\beta$ glucosidase from Melanocarpus sp. MTCC 3922 (Lineweaver-Burk plot). The amount of protein used for the study was $1.99 \mu \mathrm{g} / \mathrm{ml}$.

Transglycosylation. A reaction mixture $\left(\begin{array}{lll}150 & \mu l\end{array}\right)$ comprising of purified $\beta$-glucosidase enzyme $(1 \mu \mathrm{g})$, different concentrations $(20-100 \% \mathrm{v} / \mathrm{v})$ of methanol $(50 \mu \mathrm{l})$ and acetate buffer $(50 \mathrm{mM}, \mathrm{pH} 5.0)$ was prepared. The reaction was initiated by adding $50 \mu \mathrm{l}$ of pNPG $(10 \mathrm{mM})$ and incubating the contents at $50^{\circ} \mathrm{C}$ for $60 \mathrm{~min}$, the reaction was terminated by boiling the sample for $10 \mathrm{~min}$. To demonstrate the transglycosylation, $25 \mu \mathrm{l}$ of the aliquot from the above reaction was mixed with $0.54 \mu \mathrm{g}$ of purified endoglucanase $(40 \mathrm{kDa})$ from Melanocarpus sp. MTCC 3922 , used as revealing enzyme, and acetate buffer (50 $\mathrm{mM}, \mathrm{pH}$ 5.0) to make final volume to $100 \mu \mathrm{l}$. The reaction was carried out at $50^{\circ} \mathrm{C}$ for $60 \mathrm{~min}$. To the controls (boiled transglycosylation product) no endoglucanase was added. The reaction was terminated by adding $100 \mu \mathrm{l}$ of NaOHglycine buffer $(0.4 \mathrm{M}, \mathrm{pH} 10.8)$. The developed yellow colour was read at $405 \mathrm{~nm}$ using ELISA Reader (MULTISKAN; Labsystems).

All experiments were performed in triplicate and results are given as mean value. The standard error ranged between 1$5 \%$.

\section{RESULTS}

\section{Culture}

A new strain of Melanocarpus sp. MTCC 3922, isolated from the composting soil, grew profusely as white, cottony hyphal mass at $45^{\circ} \mathrm{C}$ and touched the lid of plate within 2-3 days of incubation. Due to the lack of sporulation and mating type for bringing about the ascospore formation,
(MTCC), Chandigarh, identified this true thermophilic heterothallic ascomycete as Melanocarpus sp. MTCC 3922.

\section{Purification of $\beta$-glucosidase}

An extracellular $\beta$-glucosidase from Melanocarpus sp. was purified by ion exchange chromatography using DEAESepharose (weak anion exchanger) and PBE 94 (Strong ion exchanger) columns. During DEAE-Sepharose column chromatography, the major $\beta$-glucosidase peak was eluted with $0.4 \mathrm{MNaCl}$ gradient; this peak also contained contaminating endoglucanase activities. Finally on PBE 94 column, $\beta$-glucosidase peak was separated from endoglucanase at $0.5 \mathrm{M} \mathrm{NaCl}$ gradient. The results of purification procedure are summarized in Table 1. The purified enzyme preparation exhibited a specific activity of $10.04 \mu \mathrm{mol} \mathrm{min}{ }^{-1} \mathrm{mg}$ protein ${ }^{-1}$, while purification fold and yield were 4.06 and $15.89 \%$, respectively.

Purified $\beta$-glucosidase from Melanocarpus sp. was homogeneous as judged by SDS-PAGE, gel filtration, and IEF-PAGE. The molecular weight of $\beta$-glucosidase, estimated by gel filtration and SDS-PAGE, was 102 and 92 $\mathrm{kDa}$, respectively. Further homogeneity was confirmed by IEF that showed single band of $\beta$-glucosidase with $\mathrm{p} I$ value of $\sim 4.1$ (Figure 1a and Figure 1b, respectively).

\section{Temperature, pH optima and stability}

$\beta$-Glucosidase was optimally active at $60^{\circ} \mathrm{C}$ and at $\mathrm{pH} 6.0$ (Figure 2a). Above $70^{\circ} \mathrm{C}$, the enzyme showed less than $25 \%$ of its optimal activity. However, maximum activity was observed at $\mathrm{pH} 6.0$ at $50^{\circ} \mathrm{C}$ (Figure 2b) and less than $10 \%$ relative activity was observed at $\mathrm{pH} 3.0-4.0$ and 9.0-10.0. $\beta$ Glucosidase was stable (Figure 3 ) at $50^{\circ} \mathrm{C}$ and $\mathrm{pH} 5.0$ and 6.0. The enzyme retained $100 \%$ of its original activity at $\mathrm{pH}$ 5.0 and 6.0 for $200 \mathrm{~min}$; whereas, $64.0 \%$ relative activity was retained at $\mathrm{pH} 5.0$ and 6.0 after $360 \mathrm{~min}$ of incubation at $50^{\circ} \mathrm{C}$. The enzyme was less stable at $60^{\circ} \mathrm{C}$ and $\mathrm{pH} 5.0$ and lost more than $80.0 \%$ activity after $30 \mathrm{~min}$. While at $\mathrm{pH}$ 6.0 , approximately $55.0 \%$ relative activity was lost after 30 $\min$.

\section{Effect of metal ions and other chemical reagents on $\beta$-glucosidase}

$\beta$-Glucosidase showed enhanced activity in presence of reducing agents, DTT and mercaptoethanol (Figure 4). The presence of monovalent and divalent metal ions $\mathrm{Na}^{+}, \mathrm{K}^{+}$, $\mathrm{Ca}^{2+}, \mathrm{Mg}^{2+}$ and $\mathrm{Zn}^{2+}$ also positively influenced the activity of $\beta$-glucosidase. The presence of EDTA and SDS did not inhibit the enzyme activity, whereas, $\mathrm{CuSO}_{4}$ inhibited the enzyme activity up to $38.0 \%$.

\section{Substrate specificity of $\beta$-glucosidase activity}

The action of purified $\beta$-glucosidase was tested over different substrates with $\alpha$ and $\beta$ configurations. The results summarized in Table 2 show that $\beta$-glucosidase was maximally active against pNPG. $\beta$-Glucosidase activity on 


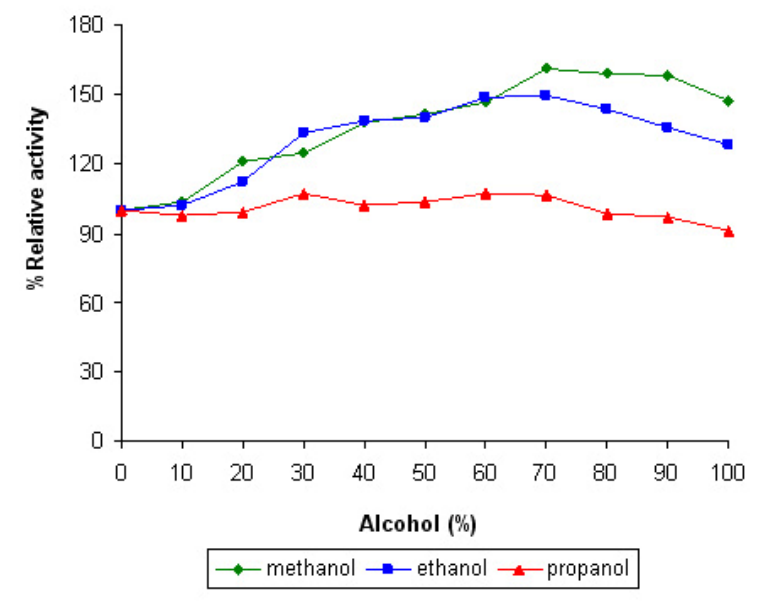

Figure 6. Effect of different \% (v/v) of methanol, ethanol, and propan-2-ol $(\Delta)$ on the $\beta$-glucosidase activity of Melanocarpus sp. MTCC 3922.

pNP- $\beta$-D-cellobioside was only $4.69 \%$ of that on pNPG. No activity was observed in the presence of the nitro group at the ortho position in oNP- $\beta$-D-galactopyranoside, oNP$\beta$-D-xylopyranoside, as well as pNP- $\beta$-D-galactopyranoside and pNP-xylopyranoside. $\beta$-Glucosidase recognized cellobiose and salicin as substrate, however, enzyme was inactive against $\mathrm{CMC}$ (low and high viscosity), Avicel, Solka floc, laminarin and birchwood xylan.

\section{Inhibition}

The effect of different mono and disaccharides were studied in presence of pNPG. The results in Table 3 revealed that in the presence of glucose, $\sim 47.0 \%$ decrease in hydrolysis of pNPG was observed. However, low level of inhibition was observed in presence of xylose, galactose and sucrose.

\section{Kinetics}

$K_{m}$ and $V_{\max }$ for the hydrolysis of pNPG by $\beta$-glucosidase was determined using $0-10 \mathrm{mM}$ substrate and analyzed the data from Lineweaver-Burk plots (Figure 5). From this plot the values of $K_{\mathrm{m}}$ and $V_{\max }$ were calculated as $3.3 \mathrm{mM}$ and 43.68 : molmin $^{-1} \mathrm{mg}$ protein ${ }^{-1}$, respectively for $\mathrm{pNPG}$. The $\mathrm{k}_{\text {cat }}$ towards pNPG was $4 \times 10^{3} \mathrm{~min}^{-1}$.

\section{Effects of alcohols}

The results in Figure 6 showed that short chain length alcohols, methanol and ethanol at a final concentration of $70 \%(\mathrm{v} / \mathrm{v})$ increased the activity of $\beta$-glucosidase by 1.5 folds, while $70 \%(\mathrm{v} / \mathrm{v})$ propan-2-ol has no effect on the enzyme activity but propan-2-ol between 80 and 100\% $(\mathrm{v} / \mathrm{v})$ resulted in the inhibition of the enzyme activity.

\section{Transglycosylation}

The results in Figure 7 showed that in the presence of $20 \%$ $(\mathrm{v} / \mathrm{v})$ methanol, low transglycosylation activity was observed but as the methanol level was increased to $60 \%$ $(\mathrm{v} / \mathrm{v})$ there was a steady increase in transglycosylation activity. Further increase in methanol concentration resulted in decrease in activity.

\section{DISCUSSION}

The thermophilic fungus, Melanocarpus sp. MTCC 3922, isolated from composting soil and used in the present study, is a rare fungus which produced very high amount of $\beta$ glucosidase $(132.4 \mathrm{U} / \mathrm{g}$ of substrate) when rice straw was used as carbon source under solid-state fermentation. This is first report on the purification and characterization of $\beta$ glucosidase from Melanocarpus sp. MTCC 3922. Previously, we have shown that Melanocarpus sp. expressed only one isoform of $\beta$-glucosidase with acidic $\mathrm{p} I$ in the presence of rice straw, when crude filtrate was resolved on IEF gels (Kaur et al. 2006). The enzyme was purified to homogeneity with specific activity of 10.04 $\mu \mathrm{mol} \mathrm{min}{ }^{-1} \mathrm{mg}$ protein ${ }^{-1}$ and yield (\%) 15.89. The molecular weight of the native $\beta$-glucosidase estimated by gel filtration was $102 \mathrm{kDa}$, and by SDS-PAGE analysis was about $92 \mathrm{kDa}$ suggesting that the enzyme is a monomer.

Table 3. Effect of various mono- or di-saccharides on $\beta$ glucosidase activity of Melanocarpus sp. MTCC 3922.

\begin{tabular}{|l|c|}
\hline \multicolumn{1}{|c|}{ Substrate $^{\text {a }}$} & Relative activity (\%) \\
\hline Control & 100 \\
\hline \multicolumn{2}{|c|}{ Monosaccharides } \\
\hline Glucose & 53.34 \\
\hline Arabinose & 72.36 \\
\hline Xylose & 75.31 \\
\hline Galactose & 76.44 \\
\hline Fructose & 73.49 \\
\hline \multicolumn{2}{|c|}{ Disaccharides } \\
\hline Sucrose & 76.55 \\
\hline Cellobiose & 72.36 \\
\hline Salicin & \\
\hline
\end{tabular}

${ }^{a}$ Various monosaccharides and disaccharides were added @ $1 \mathrm{mg} / \mathrm{ml}$ to the control containing PNPG as substrate. 


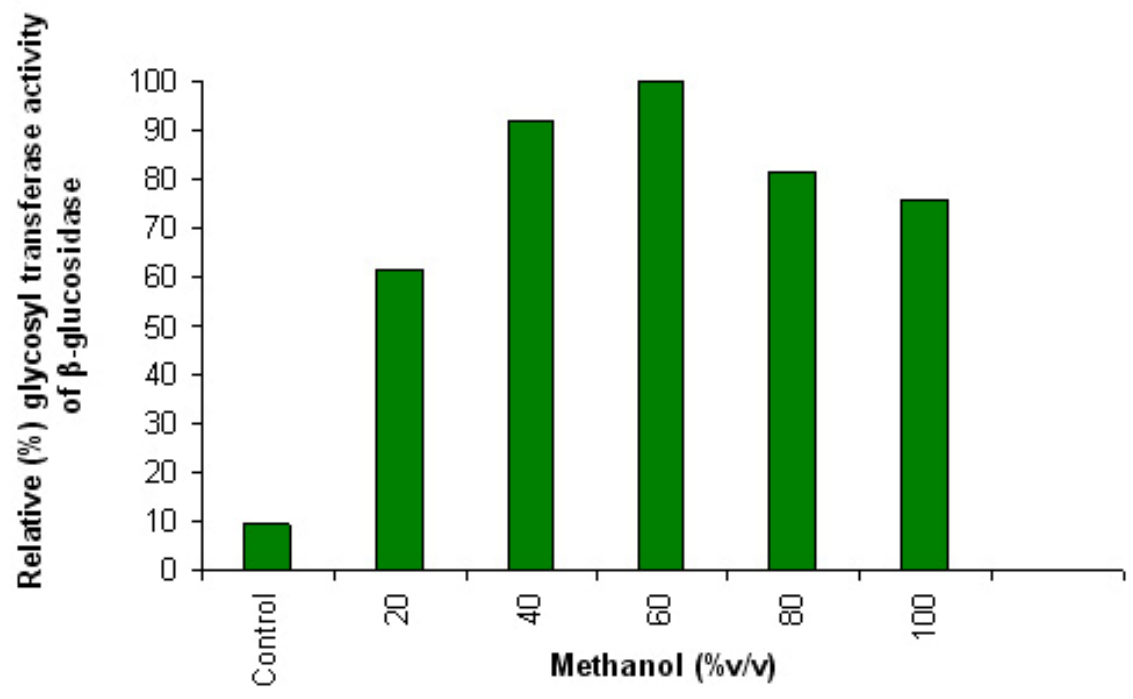

Figure 7. Effect of different \% (v/v) of methanol on the glycosyl-transferase activity of $\beta$-glucosidase of Melanocarpus sp. MTCC 3922.

This property is shared with Trichoderma harzianum and Acremonium persicinum having single protein of molecular weight of $75 \mathrm{kDa}$ and $128 \mathrm{kDa}$, respectively (Pitson et al. 1997; Yun et al. 2001). But it was different from $\beta$ glucosidase of Pichia etchellsii and Thermoascus aurantiacus, which had high molecular weights and oligomeric nature (Pandey and Mishra, 1997; Parry et al. 2001). Furthermore, the purity of enzyme was confirmed by isoelectric focusing which showed a single protein band. The purified enzyme has acidic $\mathrm{p} I$, which has also been observed in A. niger and Fusarium oxysporum ( $\mathrm{p} I$ 3.2, 3.8, respectively) (Christakopoulos et al. 1994; Yan and Lin, 1997).

The maximum activity for the enzyme was observed at $\mathrm{pH}$ 6.0 and $60^{\circ} \mathrm{C}$, which is similar to $\beta$-glucosidase purified from Thermomyces lanuginosus (Lin et al. 1999). The optimal conditions for most $\beta$-glucosidase from other fungus (Bhat et al. 1993; Alconada and Martinez, 1996; Wei et al. 1996) are near $\mathrm{pH} 6.0$ and from $45-65^{\circ} \mathrm{C}$. $\beta$ Glucosidase from Melanocarpus sp. was not active in the extreme $\mathrm{pH}$ of either 3 or 10 . The $\mathrm{pH}(5-6)$ and the thermostability at $50^{\circ} \mathrm{C}$ for 240 min were with in the range of most of fungal $\beta$-glucosidases (Bhat et al. 1993; Wei et al. 1996). An increase in $\beta$-glucosidase activity in presence of DTT and mercaptoethanol indicated the absence of thiol groups at catalytic sites.

$\beta$-Glucosidase from Melanocarpus sp. was preferentially active against $\mathrm{pNP}-\beta$-glucopyranoside when compared to cellobiose. Enari and Niku-Paavola (1987) classified $\beta$ glucosidases into three major groups according to their substrate specificity; (1) aryl $\beta$-glucosidases with a strong affinity for aryl $\beta$-glucosides; (2) cellobiases, which only hydrolyze oligosaccharides (including cellobiose); and (3) $\beta$-glucosidases that are active with both type of substrates. Our results showed that $\beta$-glucosidase purified from Melanocarpus sp. MTCC 3922 was active against both aryl $\beta$-glucosides and cellobiose therefore it can be concluded that $\beta$-glucosidase from Melanocarpus sp. belong to group 3.

Plant et al. (1988) suggested that the preference of $\beta$ glucosidases for aryl glycosides is due to the high electrophilicity of the aglycone moiety, which enhances the stability of the ortho or para nitrophenoxide anion generated during the first step of catalysis. $\beta$-Glucosidase from Melanocarpus sp. showed broad specificity towards diglycosides. $\beta$-Glucosidase from Melanocarpus sp. was found to hydrolyze cellobiose to a greater and salicin to lesser extent indicating no steric hindrance with this compound as also observed in Humicola grisea (Takashima et al.1996) and Candida peltata (Saha and Bothast, 1996). Kinetic study revealed that $\beta$-glucosidase from Melanocarpus sp. has lower value of $K_{m}(3.3 \mathrm{mM})$ for pNPG than Cellulomonas biazotea $(4.25 \mathrm{mM})$ and Aspergillus niger CCRC $31494(21.7 \mathrm{mM})$ thus indicating higher affinity of enzyme for pNPG substrate (Siddiqui et al. 1997; Yan and Lin, 1997). $\beta$-Glucosidase from Melanocarpus sp. was free of endoglucanase, avicelase, xylanase, $\beta$-D-galactosidase and arabinofuranosidase activity thus possessed high specificity, though, multiplefunctionality is common among other $\beta$-glucosidases that shows galactosidase and xylosidase activities (Lin et al. 1999).

Presence of methanol and ethanol had a positive influence on the hydrolytic activity of $\beta$-glucosidase. In the presence of methanol and ethanol, an increase in enzyme activity was observed, though, the activity decreased with the 
longer alcohol chains. Activation by alcohol has been earlier observed for $\beta$-glucosidase from Thermoascus aurantiacus (Parry et al. 2001), Aspergillus oryzea (Riou et al. 1998), Fusarium oxysporum (Christakopoulos et al. 1994). $\beta$-Glucosidase from Melanocarpus sp. showed high transglycosylation activity in the presence of methanol. Transglycosylation was determined following the concept of using secondary reactions of a primary reaction product to induce a recordable signal (Mayer et al. 2001). The pNPG was used as donor and methanol as an acceptor. The primary reaction was catalyzed using purified $\beta$-glucosidase enzyme. To monitor the transglycosidase activity, purified endoglucanase (molecular weight $\sim 40 \mathrm{kDa}$ ) was used as a revealing enzyme. The observations indicated the transglycosylation in the presence of methanol by $\beta$ glucosidase. Although purified endoglucanase did not cleave pNPG, but enzyme hydrolyzed the polysaccharide formed by transglycosylation and released yellow nitrophenol as signal indicating putative transglycosylation activity (Mayer et al. 2001). Previously, we have shown purified endoglucanase from Melanocarpus sp. exhibiting processive activity against crystalline cellulose and filter paper (Kaur et al. 2007). Presence of methanol resulted in higher levels of transglycosylation. Parry et al. (2001) have previously shown that methanol enhances the glycosyltransferase activity of $\beta$-glucosidase in thermophilic ascomycete Thermoascus aurantiacus. Similarly Matsumura et al. (1999) also reported direct transglycosylation of xylan and octanol to octyl $\beta$-Dxylobioside by purified xylanase of Aureobasidium pullulans.

Expectedly, $\beta$-glucosidase from Melanocarpus sp. exhibited synergistic interaction with endoglucanase to increase the efficiency of glucose production from cellulose by converting rice straw to glucose (data not shown) indicating utility of $\beta$-glucosidase in enzymatic hydrolysis of cellulosics for subsequent production of ethanol fuel. The observed high activity of $\beta$-glucosidase from Melanocarpus sp. on rice straw also makes it a promising candidate for application in bioconversions as well as catalysis of novel compounds through transglycosylation reactions.

\section{REFERENCES}

ALCONADA, T.M. and MARTINEZ, M.J. Purification and characterization of a beta-glucosidase from the phytopathogenic fungus Fusarium oxysporum sp. melonis. Letters in Applied Microbiology, 1996, vol. 22, no. 2, p. 106-110.

BHAT, M.K. and BHAT, S. Cellulose degrading enzymes and their potential industrial application. Biotechnology Advances, 1997, vol. 15, no. 3, p. 583-620.

BHAT, M.K.; GAIKWAD, J.S. and MAHESHWARI, R. Purification and characterization of an extracellular $\beta$ glucosidase from the thermophilic fungus Sporotrichum thermophile and its influence on cellulase activity. Journal of General Microbiology, 1993, vol. 139, no. 11, p. 28252832.

BRADFORD, Marion M. A rapid and sensitive method for the quantification of microgram quantities of protein utilizing the principle of protein-dye binding. Analytical Biochemistry, May 1976, vol. 72, no. 1-2, p. 248-254.

CALDINI, Claudio; BONOMI, Francesco; PIFFERI, Pier Giorgio; LANZARINI, Gaetano and GALANTE, Yves M. Kinetic and immobilization studies on fungal glycosidases for aroma enhancement in wine. Enzyme and Microbial Technology, April 1994, vol. 16, no. 4, p. 286-291.

CHRISTAKOPOULOS, P.; GOODENOUGH, P.W.; KEKOS, D.; MACRIS, B.J.; CLAEYSSENS, M. and BHAT, M.K. Purification and characterization of an extracellular $\beta$-glucosidase with transglycosylation and exo-glucosidase activities from Fusarium oxysporum. European Journal of Biochemistry, September 1994, vol. 224, no. 2, p. 379-385.

ENARI, T.M. and NIKU-PAAVOLA, M.L. Enzymatic hydrolysis of cellulose: Is the current theory of the mechanism of hydrolysis valid? Critical Reviews in Biotechnology, 1987, vol. 5, p. 67-87.

HARHANGI, Harry R.; PETER, J.M. Steenbakkers; AKHMANOVA, Anna; JETTEN, Mike S.M.; VAN DER DRIFT, Chris and OP DEN CAMP, Huub J.M. A highly expressed family $1 \beta$-glucosidase with transglycosylation capacity from the anaerobic fungus Piromyces sp. E2. Biochimica et Biophysica Acta, April 2002, vol. 1574, no. 3, p. 293-303.

IWASHITA, Kazuhiro; TODOROKI, Kouichi; KIMURA, Hitoshi; SHIMOI, Hitoshiand and ITO, Kiyoshi. Purification and characterization of extracellular and cell wall bound $\beta$-glucosidases from Aspergillus kawachii. Bioscience, Biotechnology and Biochemistry, October 1998, vol. 62, no. 10, p. 1938-1946.

JERKOVIĆ, Igor and MASTELIĆ, Josip. GC-MS characterization of acetylated $\beta$-D-glucopyranosides: Transglucosylation of volatile alcohols using almond $\beta$ glucosidase. Croatica Chemica Acta, October 2004, vol. 77 , no. 3 , p. $529-535$.

KAUR, Jatinder; CHADHA, Bhupinder S. and SAINI, Harvinder S. Optimization of medium components for production of cellulases by Melanocarpus sp. MTCC 3922 under solid-state fermentation. World Journal of Microbiology and Biotechnology, January 2006, vol. 22, no. 1, p. 15-22.

KAUR, Jatinder; CHADHA, Bhupinder S.; KUMAR, Badhan A. and SAINI, Harvinder S. Purification and characterization of two endoglucanases from Melanocarpus 
sp. MTCC 3922. Bioresource Technology, January 2007, vol. 98 , no. 1, p. 74-81.

LAEMMLI, U.K. Cleavage of structural proteins during the assembly of the head of bacteriophage $\mathrm{T}_{4}$. Nature, August 1970 , vol. 227 , no. 5259, p. 680-685.

LIN, Johnson; PILLAY, Balakrishna and SINGH, Suren. Purification and biochemical characterization of $\beta$ glucosidase from a thermophilic fungus, Thermomyces lanuginosus - SSBP. Biotechnology and Applied Biochemistry, August 1999, vol. 30, no. 1, p. 81-87.

MAHESHWARI, Ramesh; BHARADWAJ, Girish and BHAT, Mahalingeshwara K. Thermophilic fungi: their physiology and enzymes. Microbiology and Molecular Biology Reviews, September 2000, vol. 64, no. 3, p. 461488.

MAHESHWARI, R. and KAMALAM, P.T. Isolation and culture of a thermophilic fungus, Melanocarpus albomyces, and factors influencing the production and activity of xylanase. Journal of General Microbiology, 1985, vol. 131, no. 11, p. 3017-3027.

MATSUMURA, Shuichi; SAKIYAMA, Kazuya and TOSHIMA, Kazunobu. Preparation of octyl- $\beta$-Dxylobioside and xyloside by xylanase-catalyzed direct transglycosylation reaction of xylan and octanol. Biotechnology Letters, January 1999, vol. 21, no. 1, p. 1722.

MAYER, Christoph; JAKEMAN, David L.; MAH, Melanie; KARJALA, Geoff; GAL, Laurent; WARREN, R.A.J. and WITHERS, Stephen G. Directed evolution of new glycosynthases from Agrobacterium $\beta$-glucosidase: a general screen to detect enzymes for oligosaccharide synthesis. Chemistry and Biology, May 2001, vol. 8, no. 5, p. $437-443$.

OH, Ki-Bong; HAMADA, Kazu; SAITO, Mikako; LEE, Hun-Jun and MATSUOKA, Hideaki. Isolation and properties of an extracellular $\beta$-glucosidase from a filamentous fungus, Cladosporium resinae, isolated from kerosene. Bioscience, Biotechnology and Biochemistry, 1999, vol. 63, no. 2, p. 281-287.

PANDEY, Manjula and MISHRA, Saroj. Expression and characterization of Pichia etchellsii $\beta$-glucosidase in Escherichia coli. Gene, April 1997, vol. 190, no. 1, p. 4551.

PARRY, Neil J.; BEEVER, David E.; OWEN, Emyr; VANDENBERGHE, Isabel; VAN BEEUMEN, Jozef and BHAT, Mahalingeshwara K. Biochemical characterization and mechanism of action of a thermostable $\beta$-glucosidase purified from Thermoascus aurantiacus. Biochemical Journal, January 2001, vol. 353, no. 1, p. 117-127.
PITSON, Stuart M.; SEVIOUR, Robert J. and MCDOUGALL, Barbara M. Purification and characterization of an extracellular $\beta$-glucosidase from the filamentous fungus Acremonium persicinum and its probable role in $\beta$-glucan degradation. Enzyme and Microbial Technology, August 1997, vol. 21, no. 3, p. 182190.

PLANT, Adrian R.; OLIVER, Janice E.; PATCHETT, Mark L.; DANIEL, Roy M. and MORGAN, Hugh W. Stability and substrate specificity of a $\beta$-glucosidase from the thermophilic bacterium Tp8 cloned into $E$. coli. Archives of Biochemistry and Biophysics, April 1988, vol. 262, no. 1, p. 181-188.

RECZEY, K.; BRUMBAUER, A.; BOLLOK, M.; SZENGYEL, Z. and ZACCHI, G. Use of hemicellulose hydrolysate for $\beta$-glucosidase fermentation. Applied Biochemistry and Biotechnology, 1998, vol. 70-72, p. 225235.

RIOU, Christine; SALMON, Jean-Michel; VALLIER, Marie-Jose; GÜNATA, Ziya and BARRE, Pierre. Purification, characterization, and substrate specificity of a novel highly glucose-tolerant $\beta$-glucosidase from Aspergillus oryzae. Applied and Environmental Microbiology, October 1998, vol. 64, no. 10, p. 3607-3614.

SAHA, B.C and BOTHAST, R.J. Production, purification, and characterization of a highly glucose-tolerant novel $\beta$ glucosidase from Candida peltata. Applied and Environmental Microbiology, September 1996, vol. 62, no. 9, p. 3165-3170.

SARRY, Jean-Emmanuel and GUNATA, Ziya. Plant and microbial glycoside hydrolases: volatile release from glycosidic aroma precursors. Food Chemistry, October 2004, vol. 87 , no. 4 , p. 509-521.

SIDDIQUI, K.S.; RASHID, M.H.; GHAURI, T.M.; DURRANI, I.S. and RAJOKA, M.I. Purification and characterization of an intracellular $\beta$-glucosidase from Cellulomonas biazotea. World Journal of Microbiology and Biotechnology, March 1997, vol. 13, no. 2, p. 245-247.

TAKASHIMA, S.; NAKAMURA, A.; MASAKI, H. and UOZUMI, T. Purification and characterization of cellulases from Humicola grisea. Bioscience, Biotechnology and Biochemistry, 1996, vol. 60, no. 1, p. 77-82.

VAN RENSBURG, Pierre; VAN ZYL, Willem H. and PRETORIUS, Isak S. Engineering yeast for efficient cellulose degradation. Yeast, January 1998, vol. 14, no. 1, p. 67-76.

WEI, Ding-Ling; KIRIMURA, Kohtaro; USAMI, Shoji and LIN, Tsung-Hui. Purification and characterization of an extracellular $\beta$-glucosidase from the wood-grown fungus Xylaria regalis. Current Microbiology, November 1996, vol. 33, no. 5, p. 297-301. 
YAN, Tsong-Rong and LIN, Chun-Lieh. Purification and characterization of a glucose-tolerant $\beta$-glucosidase from Aspergillus niger CCRC 31494. Bioscience, Biotechnology and Biochemistry, June 1997, vol. 61, no. 6, p. 965-970.

YANG, J.L.; MA, J.; PIERCE, J.M. and ERIKSSON, K.E.L. Composition for enzymatic deinking of waste paper, U.S. Patent 5454389, August 1999.

YUN, Soo-In; JEONG, Choon-Soo; CHUNG, Dae-Kyun and CHOI, Hye-Seon. Purification and some properties of a beta-glucosidase from Trichoderma harzianum type C-4. Bioscience, Biotechnology and Biochemistry, September 2001, vol. 65, no. 9, p. 2028-2032. 